\title{
Bound forms, welded forms, and affixes: Basic concepts for morphological comparison
}

\author{
Martin Haspelmath \\ Max Planck Institute for Evolutionary Anthropology, Leipzig, Germany; \\ Leipzig University, Leipzig, Germany; martin_haspelmath@eva.mpg.de
}

\begin{abstract}
This paper proposes definitions of three terms that can potentially be used in answering key questions of general morphology and syntax: bound form, welded form, and affix. The term affix is sometimes thought to involve phonological "fusion" of some kind, but I propose that it is best defined as a bound non-root that cannot occur on roots of different classes. A bound form (or non-autonomous form) is generally defined as a form that does not occur on its own (thus, its definition makes no reference to phonology). As a term for a bound form that shows phonological interactions with its host, I propose the new term welded form. I discuss the ways in which these terms may (or may not) help us justify the syntax-morphology subdivision, and the ways in which these terms may perhaps be the basis for justifying speculative classifications such as the well-known isolating, agglutinative and flective types.
\end{abstract}

Keywords: affix, agglutination, alternations, morpheme, morphology, wordhood

Acknowledgements: I have discussed the issues of this paper with many colleagues over the years, but I would like to single out Matthew Dryer, David Gil, Chao Li, Östen Dahl, and Harald Hammarström for making particularly useful contributions to my thinking. I also thank two anonymous reviewers for Voprosy Jazykozanija that made extremely good comments which helped me improve the paper. The support of the European Research Council (ERC Advanced Grant 670985, Grammatical Universals) is gratefully acknowledged.

For citation: Haspelmath M. Bound forms, welded forms, and affixes: Basic concepts for morphological comparison. Voprosy Jazykoznanija, 2021, 1: 7-28.

DOI: $10.31857 / 0373-658 X .2021 .1 .7-28$

\section{Связанные формы, спаянные формы и аффиксы: Базовые понятия для морфологического сопоставления}

\section{Мартин Хаспельмат}

Институт эволюционной антропологии Макса Планка, Лейпциг, Германия; Лейпцигский университет, Лейпциг, Германия; martin_haspelmath@eva.mpg.de

Аннотация: В статье предлагаются определения для трех понятий, которые, предположительно, могут быть использованы в решении ключевых вопросов общей морфологии и синтаксиса: связанная форма, спаянная форма и аффикс. Иногда считается, что понятие аффикса подразумевает некую фонологическую «фузию», но я предлагаю определять его просто как связанный морф, не являющийся корнем и сочетающийся с корнями только одного класса. Связанная (или неавтономная) форма определяется как форма, не употребляющаяся изолированно (таким образом, и ее определение не опирается на фонологию). Для связанной формы, фонологически взаимодействующей с опорным элементом, я предлагаю новый термин спаянная форма (welded form). Я рассматриваю вопрос о том, как эти понятия могут пригодиться (или не пригодиться) 
для того, чтобы эмпирически обосновать разграничение морфологии и синтаксиса, а также умозрительные классификации типа известного деления языков на изолирующие, агглютинативные и флективные.

Ключевые слова: агглютинация, аффикс, морфема, морфология, слово, чередования

Для цитирования: Haspelmath M. Bound forms, welded forms, and affixes: Basic concepts for morphological comparison. Voprosy Jazykoznanija, 2021, 1: 7-28.

DOI: $10.31857 / 0373-658 X .2021 .1 .7-28$

\section{Introduction: Three definitions and five principles}

In this paper, I propose and discuss the following definitions of three important concepts that we need for comparing languages in terms of their morphosyntactic properties.

\section{(1) bound form (§4)}

A bound form is a form that cannot occur on its own.

(2) welded form $(\S 5)$

A welded form is a bound form which has shape variants phonologically conditioned by its host, or which phonologically conditions shape variants of its host.

(3) affix (\$6)

An affix is a bound morph that is not a root, that must occur on a root, and that cannot occur on roots of different root classes.

Morphological typology is an area where traditional stereotypes abound, so it is particularly important to be critical of our traditional terminology. Plungian [2000: 81] hints at the problematic nature of two traditional terms when he says in his discussion of the terms root and affix: "I do not know a single effective definition of root and affix".

The present discussion will be based on the following five principles for good general terminology of linguistics (note that I am talking about general terms for general linguistics, not about terms for particular phenomena in particular languages).

(4) A. All terms intended for technical use should be clearly defined on the basis of other well-defined terms, or on the basis of widely understood (quasi-)primitive terms.

B. Frequently used terms should be defined in a simple way, so that first-year students of linguistics can be expected to understand and remember the definitions.

C. The range of application of the definition of a widely used term should not deviate substantially from its traditional range of application.

D. General concepts are comparative concepts (defined in the same way for all languages), because each language has its own building blocks.

E. A term's general definition is a comparative definition and thus need not cover the entire domain of what a corresponding language-particular category covers. In other words, shared-core definitions of general terms $(\$ 7)$ are fully acceptable.

Before discussing the three definitions in (1)-(3) further (below in $\S \S 4-6$ ), I will briefly review some reasons for the need for clear definitions $(\$ 2)$ and I will remind readers of the shaky basis for some of the stereotypical terms of traditional "morphological typology" $(\S 3)$. 


\section{Why we need clear definitions}

The need for clear definitions of technical scientific terms would seem to be completely uncontroversial, but in actual fact, linguists do not spend much energy on providing clearly defined technical terms. Our scholarly associations do not have terminology committees, and my personal experience shows that many colleagues are not really interested in questions of terminology (although they will admit in private that our terminology is often unclear). Terminological questions are often seen as inextricably linked to substantive questions, and as long as we do not make progress on these, these colleagues do not find terminological clarity urgent.

But without clear terms, we will not be able to tell each other about whatever progress we make on substantive questions, because we will not understand each other. So we must separate our terminology from substantive questions. The latter may prove intractable for a long time to come, but terminological issues are easier to make progress on, as I would like to show here. I will discuss the three definitions in (1)-(3) and explain some of their ingredients (so that they comply with principle A), and I hope that it will become clear that the definitions of the frequently used terms bound form and affix also comply with the principles B and C.

In the domain of morphology, which has been the subject of linguists' descriptions for hundreds of years, a particular problem that is not widely recognized is the existence of powerful traditional stereotypes. It would seem obvious that a science cannot make progress without ridding itself of stereotypes, but linguists have been slow to recognize these in their ways of talking about the structure of "words". We have usually taken the existence of "words" for granted, and we have traditionally treated "inflection" differently from other structures without thinking much about these decisions.

Since the beginning of the modern continuous tradition of European academic linguistics in the $16^{\text {th }}$ century, grammarians have been talking about "inflection" of "words", without worrying much about how to recognize words and how to distinguish inflection from "particles" of various types. On the other hand, lexicographers have been compiling dictionaries, with "word" entries, which are quite separate from grammatical descriptions, and typically published in different books. This practice continues until now, and the main innovation that was introduced in the $20^{\text {th }}$ century is the term "lexeme" for a "dictionary word". The term "word-form" for a "grammar word", coming from the Russian tradition (slovoforma; e.g. [Zaliznjak 1967; Mel'čuk 1993-2000]), has not become equally widespread yet (but see, for example, [Haspelmath 2002]). ${ }^{1}$ In addition, there are relationships between different lexemes that are listed in dictionaries, and these are usually described by rules of "derivation" (a $19^{\text {th }}$ century term). So we have the following stereotypical entities:

$$
\begin{array}{llll}
\text { grammar: } & \text { word-forms, } & \text { inflection } & \text { (described in paradigms) } \\
\text { dictionary: } & \text { lexeme, } & \text { derivation } & \text { (described separately) }
\end{array}
$$

But in actual fact, of course, there is a continuum between grammar and lexicon/dictionary (e.g. [Jackendoff, Audring 2020]), so terms like those in (5) are perhaps not more than artifacts of the European tradition of describing languages in two types of books. This need not be the case - it might turn out that speakers do indeed organize their mental knowledge along similar lines (e.g. [Pinker 1999]), but whether this is the case is a very difficult and unresolved substantive issue. All too often, linguists simply presuppose that there is a distinction between inflection and derivation, and between grammar and lexicon. But our current knowledge does not bear this out (see, e.g., [Plank 1994; Spencer 2013] on the non-existence of a division between inflection and derivation).

Moreover, there is a powerful stereotype of a "morphology vs. syntax" distinction. Morphologists have their own journals, handbooks and conferences, but there are serious doubts that the

${ }^{1}$ In the British tradition, the term grammatical word is sometimes used instead of word-form (cf. [Bauer 2019: 6]). 
"word" notion, which would be at the basis of such a distinction, is based on more than the traditional spelling habits of European linguists (e.g. [Haspelmath 2011a; Tallman 2020]). If one only lives in morphologists' circles, one can have many local insights and lead a happy life, but one will never find out whether morphology is a distinct domain of Human Language.

When questioned about this, linguists often say in their defense that these traditional choices have been "fruitful" or "inspiring", which is no doubt the case, but there is no reason to think that other choices could not have been equally inspiring and fruitful. And in the later $20^{\text {th }}$ century, many generative linguists thought that there was a very rich innate grammar blueprint, consisting of many dozens or even hundreds of innate elements. On that view, it made sense to hypothesize that our technical terms correspond to innate elements of the human mind. But this view has largely disappeared.

Thus, there is no way around separating our concepts (and the terms for them) from the substantive issues that we want to address. The question whether morphology is separate from syntax cannot be answered by presupposing the existence of morphology, but only by working with low-level concepts that are independent of a possible syntax/morphology distinction, and likewise independent of a possible inflection/derivation distinction. The terms bound form (1), welded form (2), and affix (3) should be usable in attempts to answer such questions because they do not depend on an answer to them. And the terms bound form and affix, which are already widely used, should have a clear and widely accepted (retro-)definition, ${ }^{2}$ because they are technical terms that linguists expect to have a clear definition.

\section{Morphological comparison and "morphological typology"}

By "morphological comparison" as used in the title, I mean the study of differences and similarities between languages and between constructions of the same language with respect to general properties of "word-size forms" (where this is a vague term for forms that are roughly of the size of words in typical European languages). So even if we do not presuppose anything about the existence of a distinct "morphological component" in any language, we may still want to address some of the old questions in this domain.

"Morphological typology" is an area with a well-known and well-rehearsed history (e.g. [Horne 1970; Comrie 1989: §2.3; Payne 2017; Arkadiev 2020]), and the "types" in (6) with their example languages are well-known stereotypes.

$\begin{array}{ll}\text { isolating } & \text { Chinese } \\ \text { agglutinative } & \text { Turkish } \\ \text { flective } & \text { Sanskrit } \\ \text { incorporating } & \text { Mohawk } \\ \text { synthetic } & \text { Latin } \\ \text { analytic } & \text { English }\end{array}$

In fact, for quite some time, the term "language typology" was strongly associated with this kind of classification of languages, and it was only with Greenberg's work (e.g. [1974]) that the term came to be applied to a broader range of phenomena.

But as with the inflection-derivation distinction and the syntax-morphology distinction, we do not know whether the types in (6) are significant. They come from the early $19^{\text {th }}$ century

\footnotetext{
${ }^{2}$ By "retro-definition", I mean a definition of an older (but undefined) term that captures the range of uses
} of that term to a very large extent. 
[F. Schlegel 1808; A.W. Schlegel 1818; Humboldt 1822], and were proposed in a period of science when racial types were popular (in particular, Johann Friedrich Blumenbach's division of human populations into Caucasian, Mongolian, Malayan, Ethiopian and American races). ${ }^{3}$ But these racial types have been thoroughly discredited for quite some time now and are agreed to be not more than racist stereotypes, which should lead linguists to ask whether their morphological stereotypes have any scientific basis.

Again, in order to find out whether languages (or types of constructions) cluster significantly in such a way that the terms in (6) have a real meaning, we need uncontroversial basic terms which we can use to test specific hypotheses (see, e.g., [Haspelmath 2009] for an attempt to test the "agglutination hypothesis").

Importantly, these basic terms must be comparative concepts (principle D), because languages cannot be compared in terms of their building blocks. Each language has its own categories (defined in terms of its own system), so for comparison, we need concepts that apply to every language in the same way, regardless of the specifics of its unique system. This also means that the definitions in (1)-(3) need not be applied in the description of particular languages — though for reasons of transparency, we should of course define a language-particular "affix" concept in a way that yields results similar to (3).

Before moving on to some further discussion of each of the three terms (bound forms in $\S 4$, welded forms in $\S 5$, and affixes in $\S 6$ ), I should note that there is no direct relationship between the concerns of this paper and the various "frameworks" that have been prominent in the literature on general morphology (a-morphous morphology, realizational morphology, Distributed Morphology, Paradigm Function Morphology, and so on). Much of the time, these works seem concerned with finding the innate building blocks of our biocognitive blueprint for grammar, ${ }^{4}$ which are hypothesized to be the same for all languages. I think that this goal is premature, because we do not know whether there are any domain-specific, let alone grammar-specific components to human linguisticality (= our biological capacity for language). Thus, I envisage a more modest goal, namely to describe and compare the structures of languages systematically and thoroughly, with the hope of finding generalizations that can eventually point us to larger causal connections of diverse kinds. This is what most linguists do anyway in practice, so the present paper should be of interest to any linguist, regardless of their wider interests and ultimate goals.

\section{Bound forms}

The first term that I discuss is the term bound (contrasting with free), which occurs in the definition of affix in (3). The term is not uncommon in the literature, but it does not seem to be very clear to many linguists what exactly it refers to, as they seem to associate boundness with phonological properties. ${ }^{5}$ However, a bound form is clearly defined in terms of lack of independent occurrence, ${ }^{6}$ as in (1) (repeated from $\S 1$ above).

\footnotetext{
${ }^{3}$ Both Wilhelm von Humboldt (originating from Berlin) and the two Schlegels (originating from Hannover) studied in Göttingen around 1790, when Blumenbach was teaching there, so the influence may even have been quite direct.

${ }^{4}$ The innate blueprint for grammar is often called "universal grammar", and sometimes simply "language faculty", e.g. in Anderson [2008: 811]: "[The] central goal of linguistics: the devising of ways to infer the properties of the human language faculty from the available data".

${ }^{5}$ A kind of sloppy terminology that one sometimes encounters is the wrong derived form "boundedness", instead of correct boundness. (Boundedness is the property of being bounded, which comes from the verb to bound or the noun boundary. By contrast, bound(ness) comes from the verb to bind.)

${ }^{6}$ I use the expressions independent occurrence, occur on its own, and occur in isolation interchangeably.
} 


\section{(1) bound form}

A bound form is a form that cannot occur on its own.

This simple and straightforward definition was given by Leonard Bloomfield (see 7a) when he first introduced this term in his book Language, and it is found in many other influential works. A selection of further quotations is given in $(7 b-f)$ (the emphasis in $(a-c)$ is in the original).

(7) a. "A linguistic form which is never spoken alone is a bound form; all others ... are free forms." [Bloomfield 1933: 160]

b. "Some forms ... have the property that on occasion they may occur as whole utterances... This property is freedom; forms that have it are free. Other segmental forms are not free, and are therefore called bound." [Hockett 1958: 168]

c. "Forms which never occur alone as whole utterances (in some normal situation) are bound forms; forms which may occur alone as utterances are free forms." [Lyons 1968: 201]

d. "Two types of bound morphemes are found attached to (free) words in many languages: clitics and affixes, in particular inflectional affixes.” [Zwicky, Pullum 1983: 502]

e. "A useful distinction which is often made is that between 'free' and 'bound' forms. A free form can make up a complete word on its own, a bound form cannot. All affixes are, by their nature, bound." [Dixon 2010: 145]

f. "We recognize the ability of words to stand alone by saying that they are free forms. Units that are incapable of standing alone, such as affixes, are correspondingly called bound forms." [Aronoff, Fudeman 2011: 35]

None of these authors link boundness to phonology, ${ }^{7}$ so it is surprising that in actual practice, linguists often talk about boundness as if it were somehow caused by a form's phonological properties (a search for "phonologically bound" on Google Ngram Viewer will readily confirm this; see also the last paragraph of §5). Now it is true that many bound forms appear phonologically deficient. For example, the Arabic person suffix -tu (as in katab-tu 'I wrote') has a short vowel, the French definite article le has a schwa vowel, and the Russian preposition $s$ 'with' has no vowel at all. In Standard Arabic, all free forms have at least a long vowel (or more than one vowel), and in French and Russian, all free forms have at least a full vowel. So these forms are phonologically different from free forms, and can be seen as deficient.

But phonological deficiency does not explain all cases of boundness. In many or most languages, there are bound forms that are not phonologically deficient. For example, German -heit (as in Weis-heit 'wis-dom') is phonologically complete, and so is Spanish -dor (as in refrigera-dor 'refrigerat-or'), but these forms do not occur on their own and are thus bound forms.

Another term pair with the same meaning as bound/free is the pair non-autonomous / autonomous (e.g. [Plungian 2000: 19]). However, these terms have not been used very widely (and note that Lehmann's [1982/2015] notion of "autonomy of a sign" is much broader).

Independent occurrence (i.e. occurrence as a non-defective utterance) ${ }^{8}$ is sometimes said to be a problematic criterion because it cannot be investigated by the usual fieldwork methods,

\footnotetext{
${ }^{7}$ Boundness should not be confused with Lehmann's [1982/2015] notion of bondedness, which is defined in very vague terms (including phonological properties): "The syntagmatic cohesion or bondedness of a sign is the intimacy with which it is connected with another sign to which it bears a syntagmatic relation. The degree of bondedness of a sign varies from juxtaposition to merger, in proportion to its degree of grammaticality" [Lehmann 1982/2015: §4.3.2]. Linguists also sometimes use the odd expression "bound morphology", which seems tautological (presumably non-bound forms are not morphological by definition).

${ }^{8}$ Of course, when someone is prevented from finishing an utterance (e.g. "a mosqui... ouch!"), the resulting partial expressions are not considered free forms, and neither are partial forms that only occur in metalinguistic uses (e.g. "the English -ing form").
} 
and because it is a matter of degree. Of course, no criterion is absolutely watertight, but I do not think that the boundness status of a form cannot be investigated by the usual methods. It may be necessary to set up entire dialogue situations and ask speakers about their naturalness, which is not so easy, but which is necessary for other phenomena anyway. Short free forms are likely to occur independently in elliptical situations, e.g. in answers to questions. Thus, water can occur on its own in English, in particular when answering a question (What would you like?), but fork cannot occur on its own. For example, when asked Would you like chopsticks or a fork?, the answer cannot be *fork, but must be a fork, showing that fork (unlike water) is not a free form in English.

One good thing about the criterion of independent occurrence is that it can very often be observed "in nature". In actual conversations, speakers utter many short free forms, e.g. OK, true, absolutely, hopefully, quickly, I don't know, and so on. Thus, these forms are easy to recognize as free forms. Recognizing bound forms as such is not so easy, because there is no positive criterion for boundness. A bound form is simply a form that is not free, i.e. that cannot occur on its own. But in practice, almost all forms that are treated by grammarians as coordinators, subordinators, discourse markers, (non-demonstrative, non-numeral) articles, flags (case-markers or adpositions), tense and aspect markers, and agreement markers are bound forms. There may be occasional cases of subordinators that can also be used as adverbs (e.g. English before), or tense-aspect auxiliaries that can be stranded in elliptical yes-no answers (e.g. the Russian future-tense auxiliary, as in Da, budet 'Yes, she will'), and these are free forms. But by and large, there does not seem to be a big practical problem in distinguishing free forms and bound forms. ${ }^{9}$

The crucial advantage of the criterion of independent occurrence is that it can be applied in exactly the same way in all languages, and this is what we need for general concepts (principle D in (4)). I know of no alternative concept that can give us a definition of "affix" and that can be applied uniformly across languages, ${ }^{10}$ so I take it as uncontroversial that we minimally need the criterion of boundness to distinguish affixes from non-affixes.

A bound form is sometimes BOUND TO a specific type of form, which is called its host (following Zwicky's [1977] terminology), which means that it may occur next to this type of form, but not next to other types of forms. For example, the English clitic 's (from is) occurs following a subject nominal, but not following an adverbial (My friend's at home; *My friend usually's at home). Affixes are bound to a root (as we will see in §6), and enclitics are bound to a preceding host. Bound prepositions like Russian $s$ 'with' will surely be said to be bound to their complement nominal (e.g. $s$ Volodej 'with Volodja'), even if they are not regarded as proclitics. But languages may also have clause-level particles that are not limited to a particular type of host. For example, the German unstressed discourse particle $j a$ cannot occur on its own, ${ }^{11}$ so it is a bound form. But it does not occur on a specific type of host, as illustrated by the examples in (8) (the particle $j a$ is not reflected in the translation, as there is no clear English counterpart).

\footnotetext{
${ }^{9}$ It may appear counterintuitive that some English nouns are free forms (water and the other mass nouns), while most are bound forms in the singular (fork and the other count nouns). Similarly, while most Russian case forms of nouns are free, Locative case forms are bound (e.g. v Moskv-e 'in Moscow' vs. *Moskv-e [Moscow-LOC], see [Plungian, Semionova 2016: 106]). But this situation is probably not uncommon, even though it has not been widely remarked upon. If there is no expectation that boundness is a particularly "deep" property of linguistic forms, it is not surprising.

${ }^{10}$ Sometimes the term "attached" is used in defining affixes, e.g. in Bauer's [2019: 124] definition of affix: "a morph which cannot stand alone in a sentence, but must be attached to a root to make a word." Bauer does not say what he means by "attached", and the first sentence of the definition suggests that the crucial property of an affix is indeed its boundness (in the sense of (1)).

${ }^{11}$ In addition to this particle, there is also a stressed discourse particle ja, and an answer particle ja 'yes'. These three elements have the same segmental shape, but very different semantic and syntactic properties, so I treat them as three different forms.
} 
(8) a. Sie arbeitet ja heute viel.

b. Heute arbeitet sie ja viel.

c. Sie arbeitet heute ja viel.

'She works a lot today.'

Thus, the term bound does not entail any kind of "attachment" to anything. It merely refers to the lack of independent occurrence. It is a separate question to what extent bound forms are not only restricted in their independence, but also positionally. Impressionistically, it is surely the case that bound forms are much more likely to be subject to rigid ordering rules than free forms. But it seems that nobody has established this empirically by actually counting. And just as there are some bound forms with multiple positional possibilities (as seen in (8)), there are also many free forms that obey strict ordering rules. For example, money and more are both free forms in English, but they can only be combined in one way (more money, not *money more).

Finally, it should be noted that a bound form need not be a minimal form (i.e. a morph). For example, Modern Greek has clitic person forms such as ton 'him', tin 'her', tus '(to) them', $t u$ 'to him', and tis 'to her'. They are bound person forms (or person indexes [Haspelmath 2013]), but they are not minimal: They can be segmented as $t o-n$ [he-ACC], $t i-n$ [she-ACC], $t$ - $u s$ [he-PL. $\mathrm{OBL}$ ], $t-u$ [he-GEN], $t i-s$ [she-GEN], because there are other forms in the language that have these kinds of suffixes. These combinations of morphs are constituents and are thus forms, ${ }^{12}$ so they are bound forms which are not morphs.

Perhaps the most interesting recent discussion of boundness is found in Boye \& Harder [2012: 29], who note that bound forms need not be grammatical forms, but grammatical forms are always bound because they are by their very nature discursively secondary. The boundness property is thus not linked to any architectural properties of language (syntax vs. morphology) or to phonological properties, but to the way languages organize information in discourse.

\section{Welded forms}

Another widely used metaphor that goes back to American linguistics of the first half of the $20^{\text {th }}$ century is "fusion": the idea that morphological elements can show degrees of "coalescence", rather than being "mechanically combined" with each other. ${ }^{13}$ Sapir [1921] gave the examples of high / heigh-t and deep / dep-th, where the root and the affix "cannot be torn apart quite so readily as could the good and -ness of good-ness". Now my question is how this metaphor can be translated into a clearly definable criterion.

First of all, it is important to distinguish two different phenomena that are often conflated when discussing the distinction between agglutination and flection: cumulation (= joint expression) of two grammatical meanings or distinctions, and phonological variation. The metaphor of "fusion" is often associated with the idea of "lack of clear morpheme boundaries" (e.g. [Bybee 1985: 45]), and of course, there are no "morpheme boundaries" in a cumulative affix like -ov

${ }^{12}$ See [Haspelmath 2020] for the definition of the terms morph and form. (A form must be a constituent, but how exactly this term is defined is not fully clear. So the notion of 'a form' must probably be taken as a quasi-primitive concept; see principle $\mathrm{A}$ in (4).)

${ }^{13}$ Sapir's [1921] use of the "mechanic" metaphor echoes F. Schlegel's [1808] contrast between "mechanic" (= agglutinative) and "organic" inflection. Schlegel was not very explicit about the meaning of the latter, but he seems to have meant the Indo-European ablaut inflection where one might see more "coalescence" of the forms. (Of course, Schlegel's organic vs. mechanic contrast was associated with a value judgement - he regarded the Indo-European patterns as superior. Sapir rejected this view, but still continued to use the "mechanic" metaphor.) 
for Genitive Plural in Russian (e.g. [Comrie 1989: 45]). But the presence of cumulation (which is widespread for case and number in conservative Indo-European languages) is quite different from the presence of phonological variation - the latter is extremely common in the world's languages. Many affixes are like -th in English heigh- $t$ and dep-th in that they either have shape variants themselves (-th vs. $-t$ ) or trigger shape variants in their host (deep vs. dep-). For such phenomena, I suggest we use the new term welded form:

\section{(2) welded form}

A welded form is a bound form which has shape variants phonologically conditioned by its host, or which phonologically conditions shape variants of its host.

A few more examples of welded forms are given in (9)-(12).

(9) welded non-roots with shape variants
a. Russian 'with'
$s$ toboj 'with you'
vs. so mnoj 'with me'
b. English indefinite article
a pear
c. German $3^{\text {rd }}$ singular
komm-t 'comes'
vs. an apple
d. Japanese past tense
mi-ta 'saw'
vs. find-et 'finds'
e. Russian reflexive suffix
$m y l$-sja 'he washed'
vs. yon-da 'read (PST)'
vs. myla-s' 'she washed'

(10) welded non-roots that condition shape variants
a. English plural
wife
vs. wive-s
b. Polish plural
Polak 'Pole'
vs. Polac-y 'Poles'
c. Romanian plural
cal 'horse'
vs. $c a-i$ 'horses'

(11) welded roots with shape variants
a. Russian 'crumple' mja-t' [crumple-INF]
vs. $m n-u$ [crumple-PRS.1SG]
b. Spanish 'say'
dig-o [say-PRs.1sG]
vs. dic-e [say-PRs.3sG]
c. Polish 'mother'
matk- $a$ [mother-NOM.SG]
vs. matc-e [mother-DAT.SG]

(12) welded roots that condition shape variants
a. Russian infinitive
mo- $\check{c}^{\prime}$ [be.able-INF] (root $\left.m o(g)-\right)$
vs. $p e-t^{\prime}$ [sing-INF]
b. Gothic nominative singular harj-is 'army'
vs. haird-eis 'shepherd'

Even though a welded form is defined as a kind of bound form, ${ }^{14}$ we may say that two elements that occur together are "welded together" if only one of them is welded in the sense of (2). For example, the two forms in pass-ed can be said to be welded together even though only the suffix is welded.

It is actually not so clear in what sense welded forms conform to the "fusion" metaphor because there is no problem with identifying the morph boundaries in (9)-(10) (and in Sapir's original examples heigh-t and dep-th, there is no problem with boundaries either). There is "coalescence" ("growing together") in the sense that two forms that are welded together

\footnotetext{
${ }^{14}$ Of course, free forms may also have shape variants that are phonologically conditioned, e.g. English write, which has the shape variants [rart] and [rair] (in writ-ing). But intuitively, the intimacy of the phonological connection between adjacent forms is relevant only to the nature of bound forms, and this is reflected in the definition in (2).
} 
typically have a history of occurring in a sequence, which made the phonological change possible.

So it seems to me that the new term welded is more suitable for the sense in (2), for which "fused" has sometimes been used. ${ }^{15}$ For example, Bybee [1985: 4-5] talks about the "degree of morpho-phonological fusion of an affix to a stem", by which she means "the extent to which the stem and affix have a morpho-phonemic effect upon one another". But note that weldedness as defined in (2) is not a matter of degree: Either a bound form is welded or it is not welded.

The sense in (2) was also prominent in Alpatov's [1985] proposal for classifying bound forms in the world's languages (see [Arkadiev 2020: §2] for recent discussion of Alpatov's paper). He distinguished three types of grammatical markers:
a. flexions:
attached directly, shape variants
b. formants:
attached directly, no shape variants
c. function words: separable by free forms

The distinction between unwelded and welded forms is very much in the spirit of Alpatov's distinction between flexions and formants (see also [Alpatov 2018]).

I should now add a few remarks about the precise meaning of shape variants in (2). There are three clear ways in which a grammatical meaning may be expressed in a variable way, exemplified by $(14 \mathrm{a}-\mathrm{c})$.

(14) a. automatic phonetic alternations

$\begin{array}{lll}\text { English } & \text { let [let] } & \text { vs. lett-ing [lerin] } \\ \text { Spanish } & \text { veo [beo] 'I see' } & \text { vs. lo veo [loßeo] 'I see it' } \\ \text { German } & \text { leb-en [le:bən] 'live' } & \text { vs. leb [le:p] 'live (IMPV)' } \\ \text { Russian } & \text { nós-it ['nositit] 'carries' } & \text { vs. nos-i [ne' sii] 'carry (IMPv)' }\end{array}$

b. morphophonological alternations (shape variants of the same form)

$\begin{array}{lll}\text { Polish } & \text { mlek-o 'milk' } & \text { vs. mlecz-ko 'milk (DIM)' } \\ \text { English } & \text { wife } & \text { vs. wive-s } \\ \text { Spanish } & \text { cont-ar 'count' } & \text { vs. cuent-o 'I count' } \\ \text { Russian } & \text { zamok 'castle' } & \text { vs. zamk-i 'castles' }\end{array}$

c. suppletive alternations (different forms)

$\begin{array}{llll}\text { English } & \text { plural } & \text { cow-s } & \text { vs. } \text { ox-en } \\ \text { Latin } & \text { future } & \text { lauda-bi-t 'will praise' } & \text { vs. audi-e-t 'will hear' } \\ \text { Russian } & \text { plural } & \text { knig-i 'books' } & \text { vs. pis'm-a 'letters' } \\ \text { M. Greek } & \text { genitive } & \text { spiti-u 'of the house' } & \text { vs. poli-s 'of the city' }\end{array}$

${ }^{15}$ One might say that there is "true fusion" of two elements if the "resulting form" shares features of both "underlying forms", as in Russian moč' 'be able' (12a), which may be said to be "fused" from mog[be.able] plus - $t$ ' [INF] (cf. [Plungian 2001: 670]). However, this presupposes an abstract analysis in terms of "underlying" and "derived" forms, which cannot be done in an objective way that would be suitable for cross-linguistic comparison and general linguistics. 
By shape variants, I mean in particular the morphophonological alternations as in (14b). The suppletive morph sets in (14c) are not included, because they are clearly different forms, not shape variants of the same form [Haspelmath 2020]. In the same way, automatic phonetic alternations of the type (14a) are typically excluded from discussions in morphology because they are regarded as being purely a matter of phonology, so they should not count as shape variants. To make this clearer, the definition in (8) could be made more precise, to say "A welded form is a bound form which has non-automatic shape variants...". I have not done this, because the definition is already fairly complex (almost too complex for principle B).

Unfortunately, while everyone agrees that the three broad types in $(14 \mathrm{a}-\mathrm{c})$ are different, linguists have not found ways of drawing clear boundaries between them, despite looking for such boundaries for decades. For example, is the English alternation between [-d] and [-t] in the English past-tense suffix an automatic alternation (14a) or a morphophonological alternation (14b)? This is hard to say, because it does not occur in other forms, and there are not many similar alternations (though the related [-s/-z] alternation in plural forms suggests that it is an automatic alternation). There was a lot of work on drawing the boundaries between automatic and morphophonological alternations in the 1980s and 1990s (often in terms of "postlexical" vs. "lexical" behaviour of "affixes" and "clitics", e.g. [Dressler 1985; Miller 1992; Anderson 1992; Halpern 1995; Kiparsky 1996; Monachesi 1999]). I do not have anything to contribute to the ways in which the boundaries should be drawn here, so I will not say more about this. ${ }^{16}$ Note also that phonologically conditioned shape variants need not be due to an adjacent bound form: In the Spanish contrast between contár and cuénto (14b), the stem change is conditioned by stress. Prosodic properties also seem to be important for many people's intuitive notion of "fusion", but they are left out of consideration here (this would be a separate project).

I conclude that the notion of welding as defined here can serve as the basis for further research to explore the intuition that phonological interactions involving bound forms have larger significance (as in Bybee 1985, and in much of the literature on "fusion" vs. "agglutination"). It seems best to avoid the vague term "fusion", and it also seems wise to avoid talking about "phonological boundness". This latter term is actually used quite commonly, but I have never seen it defined in a textbook or survey article. We saw in $\S 4$ that boundness, as usually defined in the literature, has nothing to do with phonological properties. Thus, when linguists talk (loosely) about "phonological boundness", what they actually seem to have in mind is weldedness. ${ }^{17}$

\section{Affixes}

To conclude the discussion of the three key terms that were introduced in $\S 1$, let us look at the term affix. For a long time, I was not sure how to define an affix, because the literature shows that the various criteria that have been given for distinguishing between affixes and clitics do not

\footnotetext{
${ }^{16}$ However, it is important not to confuse "(morpho-)phonological variants" with "phonologically conditioned variants", as is sometimes done. For example Alpatov [1985: 94] describes Turkish vowel harmony variants as "phonologically conditioned variation", when in fact he means "purely phonological variation" (i.e. 14a). Crucially, suppletive alternations as in (14c) may also be phonologically conditioned, even though the forms that vary are not phonologically similar (e.g. the Dutch plural suffixes -en and $-s$, whose distribution depends on the phonological properties of the host noun).

${ }^{17}$ Some linguists seem to use "phonologically bound" also when an element is somehow prosodically dependent, e.g. by lacking its own stress properties (like Ancient Greek clitics; I did this in [Haspelmath 2002: §8.2]). It is for such "obligatorily stressless" elements that one could perhaps justify the idea that phonologically deficient elements cannot occur on their own (cf. the discussion in §4). However, as just noted, I leave prosodic properties out of consideration in the definitions of this paper. By lumping several different properties together (as I did in [Haspelmath 2002]), one is not likely to find phenomena that are comparable across languages.
} 
converge [Haspelmath 2011b; 2015; Bickel, Zúñiga 2017]. The approach proposed by Zwicky \& Pullum's [1983] famous paper does not yield clear results in the world's languages.

However, once one adopts the principle E in (4), namely that our comparative definitions may be definitions of the shared core of what is found in languages, we can define affix as in (3).

\section{(3) affix}

An affix is a bound morph that is not a root, that must occur on a root, and that cannot occur on roots of different root classes.

Tense suffixes (almost) always occur on verbs, possessive prefixes always occur on nouns, and comparative suffixes always occur on adjectives. By contrast, typical clitics occur on words of various classes. For example, the Russian interrogative enclitic li can occur on verbs (znaeš' $l i$ ? 'do you know?'), adjectives (zdorov li? 'is he well?'), adverbs (zdes'li? 'here?'), and so on. Recall also the example of the German clause-level particle $j a$ in $(8 \mathrm{a}-\mathrm{c})$ above, which is not an affix even though it is a bound form. The definition in (3) does not make reference to weldedness at all, and this seems right, because some elements that are clearly not affixes are welded forms (e.g. the English indefinite article: $a$ or $a n$, depending on the phonological context).

So for a large class of elements, this definition immediately makes the right subdivisions. ${ }^{18}$ It also conforms with Alpatov's [1985: 95] definition of "function words" as opposed to "flexions/formants" (cf. 13 above): Alpatov says that the main feature of function words that distinguishes them from affixes is that "other lexical units" can occur between them and "the stems to which they belong". For example, the Russian preposition $v$ 'in' might be said to be an affix by Zwicky \& Pullum's criteria, because the shape variants $v$ and $v o$ are distributed in a partly idiosyncratic way. However, as Alpatov notes, it does not always occur immediately next to the noun ("the stem to which it belongs"), but can be separated from it by adjectives (e.g. $v$ bol'šom dome 'in (a) big house'). Plungian [2000: 21] calls this property of non-affixes separability. In the parlance of the definition in (3), we would say that the preposition $v$ can occur "on noun roots", but also "on adjective roots". Thus Russian $v$, as well as all other Russian prepositions, are not prefixes.

Another example is the English indefinite article. The shape variants $a$ and an cannot be due to an automatic phonetic alternation, but the article is not a prefix, because it can occur not only on nouns (a house, an apple), but also on prenominal adjectives (a big house, an open house).

In the same vein, Polish person-marking clitics are not "floating affixes" (e.g. [Crysmann 2006]), because they can occur on roots of different classes:
a. $W$ domu
in house
that $\quad \operatorname{did}=2 \mathrm{PL}$
'Did you do that at home?'
b. $W$ domu=ście to zrobili?
in house=2PL that did
'Idem'

to zrobili=ście?

These forms have long been a thorny problem in Polish because they are welded forms (in that they occasionally influence the shape of their host). But weldedness and affixhood can sometimes go different ways.

Now what exactly is meant by "occurring on a root"? Many affixes occur not immediately adjacent to a root, but are (or may be) separated from it by another affix, e.g. Latin person-number suffixes $(-s,-i s t i$, etc.)

${ }^{18}$ But it is not compatible with the idea that there can be "phrasal affixes" (e.g. [Anderson 1992; Börjars 2003]), although an affix may of course occur at the edge of a phrase (cf. the discussion of Japanese flags in the last paragraph of this section). 
(16)
a. lauda-s 'you praise'
b. lauda-bi-s 'you will praise'
c. lauda-v-isti 'you have praised'

These are affixes because they occur next to other elements that are affixes, too. If the future form $-b i$ and the perfect form $-v$ were not affixes, then person forms like $-s$ and -ist $i$ would not be affixes either. So we need to define the notion of "occurrence on a root" as follows:

\section{(17) occurrence on a root:}

A bound form $\mathrm{X}$ is said to occur on a root $\mathrm{Y}$ if it occurs directly next to the root or next to an affix that occurs on the root.

This gives the desired result for a large number of affixes that always occur on nouns (possessive affixes, number affixes, case affixes, various types of derivational affixes), affixes that occur on adjectives (comparative and superlative affixes, attenuative affixes, abstract-noun affixes), and affixes that occur on verbs (voice, aspect, evidentiality, tense, mood, argument affixes). ${ }^{19}$

If a bound form occurs next to another bound form that is not an affix itself, it does not qualify as an affix. Consider the Turkish examples in (18), where the question is whether person-number indexes like -sun [2sG] are suffixes.
a. gel-iyor-sun
[come-PROG-2sG]
'you are coming'
b. gel-iyor mu-sun
[come-PROG QP-2SG]
'are you coming?'
c. su $m u$
[water QP]
'water?'

Based on the spelling (and maybe also on the vowel harmony), one might think that -sun is a suffix in (18a), but it follows the question particle $m u$, as seen in (18b). This question particle is not root-specific, but can also occur on a noun (in 18c), so it is not an affix (and Turkish spelling does not treat it as such). Therefore, the bound person marker -sun is not an affix by the definition in (3).

Note also that there is no need, on the definition given here, to say which form an affix "belongs to" (cf. Alpatov's formulation earlier in this section). While it is perhaps clear that a comparative affix "belongs to" an adjective, and a plural affix "belongs to" a noun, this is much less clear in other cases, because affixes often have a larger semantic scope. Thus, a case affix may be said to belong to the entire nominal whose role it marks, and not merely to the noun. And a tense affix may be said to belong to the entire clause (or at least the entire predication) whose temporal location it expresses, not merely to the verb. But if a bound role marker always occurs on nouns, it is a case affix, and if a bound tense marker always occurs on verbs, it is a tense affix, regardless of its semantic scope.

The formulations in (3) and (17) are neutral with respect to ordering, so they do not exclude the possibility of affixes that occur on different sides of the root under different conditions. Thus, the bound person forms for objects in the Romance languages are affixes, because they always occur on verb roots. Italian object "clitics" as in (19) are discussed by Monachesi [1999] (though her reasons for a treatment as affixes rather than clitics are far more complex).

(19) Italian
a. mi da 'gives to me' (indicative)
b. da-mmi 'give to me' (imperative)

\footnotetext{
${ }^{19}$ Note that the definition is recursive in that an affix may occur next to an affix that itself occurs next to an affix, and so on.
} 
The next question is: What exactly does it mean that a bound form occurs on roots of "different classes"? Recall from principle D above that the definitions must apply in the same way to all languages, so there can only be one answer: The root classes must be the three classes in (20).
a. noun $=$ thing root
b. verb $=$ action root
c. adjective $=$ property root

It is only these three root classes that can be used in cross-linguistic comparison because they can be identified in all languages (cf. [Croft 1991; Haspelmath 2012; 2021]).

There may be other kinds of elements that we may be tempted to call "roots" (maybe "pronoun roots", or "temporal adverb roots"), but there does not seem to be any need to include them, because they are marginal in one way or another. This also means that we can define the term "root" as in (21).

(21) root

A root is a morph that denotes a thing, an action, or a property.

This is important for the definition of affix because an affix is defined as a non-root morph. There have been many attempts to distinguish affixes from roots in other ways (cf. the discussion in [Plungian 2000: §I.3.1]), but I think that we need a simple way of defining affixes, as a type of bound morphs that are not roots. (One may also say that an affix is a MARKER that cannot occur on roots of different root classes, because the term marker is best defined as a bound morph that is not a root, in the sense of (21).)

Now what about case-markers that may occur both on nouns and on adjectives (e.g. Latin hort-us nov-us 'new garden (nominative)', hort-i nov-i 'of the new garden (genitive)', etc.)? And what about gender markers that occur both on adjectives and verbs (e.g. Russian byl-a interesn- $a$ 'was interesting', with feminine singular -a)? Or plural markers that occur on nouns and adjectives (e.g. Spanish casa-s nueva-s 'new houses'). The answer is perhaps surprising: These are not affixes by the definition in (3). But I think that it is the right answer after all, as I will discuss in the next section $(\$ 7) .{ }^{20}$

However, it should be noted that while the definition of affix given in this section should be acceptable for the discipline of linguistics, this in no way implies that affixhood (or a notion of wordhood that might build on it) must be significant for understanding Human Language. It could still be that our propensity to use the term "affix" is more based on European spelling habits than on anything in languages. To see the problem, let us briefly compare Russian prepositions (e.g. $v$ 'in', $s$ 'with', $n a$ 'on') and Japanese case-markers (e.g. nominative $g a$, accusative $o$, dative $n i$ ). The former are not prefixes (as we saw), but the latter may well be suffixes, because they seem to only occur on nouns. If this is the case (see [Spencer, Otoguro 2005: §5] for discussion of these elements), then what can we conclude from this? It does not really seem to tell us anything about the nature of these forms, because it has to do with the order of nouns and adjectives: In Russian, adjectives are prenominal, so that NP-initial flags cannot be prefixes (by our definition). In Japanese, nouns are always final in the noun phrase, so NP-final flags are suffixes. But this seems to be a fact about the order of adjective and noun, not a fact about the nature of the role-marking elements (for this reason, the term flag is better suited for comparative purposes, as noted in [Haspelmath 2019]). ${ }^{21}$ Since the subdivision of grammar into mor-

\footnotetext{
${ }^{20}$ A reviewer notes that one could distinguish different degrees of word-class sensitivity. I have defined affix as showing strong sensitivity (being limited to a single root class), while stereotypical clitics show no sensitivity at all. Eventually, we want to measure such differences, and one could of course use a different cut-off point for the term affix. The choice proposed here is also driven by considerations of simplicity (principle (B) in (4); see also note 25 below).

${ }^{21}$ In Basque, an SOV language that shares some typological features with Japanese, adjectives happen to follow nouns. As a result, the Basque flags are postpositions, not suffixes, but this is hardly a significant difference between Japanese and Basque.
} 
phology and syntax seems to be (at least in part) based on the difference between affixes and "words", these accidental factors in the identification of affixes indicate that there is probably no deeper significance to this traditional subdivision.

\section{Shared-core definitions of comparative concepts}

All languages consist of extremely complex sets of forms and regularities, and they are harder to compare than the stereotypical cases may suggest. Historical linguists and lexical typologists routinely compare words of different languages based on their meanings, and study phenomena such as colexifications (e.g. [List et al. 2018]). But even very simple phenomena such as 'hand/ arm' colexification are not completely straightforward, because a language might have two different terms, with one of the terms meaning 'hand plus forearm' (cf. [Brown 2005] for discussion). So when we treat such a language in the same way as English (rather than like Russian, which has a single word, ruka, for 'hand or arm'), we are ignoring some aspects of the diversity.

But this is unavoidable, because the goal of cross-linguistic comparison cannot be complete comparison of all aspects of a language. We always need to focus on some parts where the comparison seems particularly fruitful. Bickel \& Nichols [2013] are explicit about this in their WALS chapters about morphological typology: Instead of considering the entire range of case markers and tense-aspect-mood markers, they focus on a single characteristic marker (a grammatical case marker, a past tense marker, etc.).

Likewise, technical terms that are intended for general comparison cannot be defined in such a way that they always cover the entire range of phenomena in a particular language. When retro-defining an existing term, we need to focus on the shared core of what the term denotes in the actual literature (cf. principle C and E). Since [Foley, Van Valin 1977] at the latest, it has been known that the term "subject" cannot be defined in such a way that it covers all the relevant phenomena in each individual language, and at the same time applies to all languages. So Comrie [1978] and Dixon [1979] proposed to use the terms S, A and P for those arguments of verbs that are readily comparable across languages, and Dixon used "subject" in the sense of "S or A" (what Kibrik [1997: 291] calls "principal"). This does not cover all cases, because "dative subjects", "expletive subjects" and all kinds of other phenomena in various languages are not included, but it certainly covers the shared core of what linguists have called "subject". It allows us to make general and comparative statements (e.g. "Both Russian and Persian show agreement of the verb with the subject"), even though it does not extend to special cases. The role-types S, $\mathrm{A}$ and $\mathrm{P}$ are defined with respect to a rather narrow set of verb types (single-argument changeof-state verbs, two-argument physical-effect verbs), but it is only with verbs of this type that languages behave uniformly [Haspelmath 2011a]. So strictly speaking, experiential verbs (including common perception verbs like 'see') are not included in the general definition. But in practice, this does not matter much, because there is no question which argument is the English Subject in Kim saw her. There is also no question how to call this syntactic function in English (Subject, because it matches the general "subject" quite well).

So cross-linguistic comparison removes some language-particular facts from consideration for purposes of general linguistics, but in cases like "subject", this is not a problem, because the shared core can still be compared in alignment typology in a very fruitful way. Likewise, I think that it is not a problem that the definition of affix in (3) is a shared-core definition. It does not cover all phenomena that have been called affixes in particular languages, and that we probably want to continue to call affixes. For example, Russian has several participial forms of verbs that can themselves take number-case suffixes, e.g. znajušč-aja 'knowing (NOM.SG.F)', znajušč-uju 'knowing (ACC.SG.F)', znajušč-ix 'knowing (GEN.PL)'. But these number-case suffixes occur not only on such verbs, but also on adjectives, e.g. bol'š-aja 'big (NOM.SG.F)', bol'š-uju 'big (ACC.SG.F)'. So are these elements affixes or clitics? Well, from a Russian perspective, we 
want to say that they are Russian Affixes. But from the general perspective of the definition in (3), they are not affixes. This may at first sound unintuitive, but it is no more problematic than saying that in Kim saw her, Kim is not a subject from a general perspective.

Cross-linguistic comparison must concentrate on those aspects of languages that are comparable, and as a consequence, general definitions of grammatical terms must often be defined in terms of a shared core of phenomena. Not all grammatical terms require a shared-core definition (the term bound of $\S 4$ can be used cross-linguistically in the same way as in particular languages, because the definitional criterion of independent occurrence is so simple), but many of them do. However, we have seen that it is not problematic in any way.

\section{Back to "morphological typology"}

Now that we have clear definitions of the terms bound, welded and affix, does this help us with the "morphological types" that go back to the Schlegels and Humboldt ( $\$ 3)$ ?

Let us consider a set of straightforward expressions for location in five languages, corresponding to five of the six types in (6) above.
a. Mandarin Chinese zài Shànghăi
'in Shanghai'
(isolating?)
b. Turkish
Istanbul'da
'in Istanbul'
(agglutinating?)
c. Latin
Brundisi-i
'in Brundisium'
(flective?)
d. Sanskrit
Siv-e
'in Śiva'
(synthetic?)
e. English
in Glasgow
(analytic?)

The affix concept of $\S 6$ allows us to say that the Turkish, Latin and Sanskrit markers are affixes, as opposed to the Chinese and English markers, which can occur on roots of different classes (both English and Chinese nouns may be preceded by modifying adjectives). So these examples might be taken to exemplify the common definition of isolating languages in terms of "lacking morphology". The term "analytic" does not seem to have a meaning different from "isolating" (in practice, it is not much used for classifying entire languages, but it is often used for "analytic constructions"; cf. [Haspelmath, Michaelis 2017]).

Now this might be taken as a basis for computing indexes of analyticity/isolation and syntheticity along the lines of Greenberg [1960] (see [Payne 2017: 82-87] for recent discussion). We might identify roots and affixes in corpora of different languages and count how many affixes there are in each language. ${ }^{22}$ But would this help us distinguish types that are relevant beyond this counting exercise? Recall from $\S 6$ (last paragraph) that the distinction between an affix and a non-affix may have to do with word order possibilities. This can also be illustrated by Hebrew, which has a preposed locative marker like Chinese and English.

\section{Hebrew be-Haifa 'in Haifa'}

But Hebrew has no prenominal adjectives, so the "preposition" be- is actually a prefix by the definition in $\S 6$. As a result, Hebrew but not Chinese or English would be synthetic on this count, just as Japanese but not Basque would be synthetic (see note 21). This would be consistent, but apparently unrevealing. The widespread idea that "morphology" is somehow "complex" while "isolating" structures are "simple" (cf. [Gil 2008]) is thus not straightforward at all.

\footnotetext{
${ }^{22}$ But recall that this would allow us to count only those elements that are affixes on verbs, nouns and adjectives. Elements which occur on personal pronouns, on demonstratives, on auxiliary verbs etc. could not be counted. So the counts would not be exhaustive (cf. §7), but apparently still representative.
} 
Placing a grammatical marker in a fixed position where it is always next to verb or a noun is not more complex than placing it in a fixed position where it is always at the beginning of a noun phrase or a verb phrase.

Next, what about the difference between agglutinative and flective languages? One might say that agglutinative languages are those with few welded forms, both among the roots and among the affixes, while flective languages are those with many welded forms (using the new term welded form of §5). Plungian [2001: §2.1-2] discusses the flective type in these terms, as does Payne [2017: 87]. So what about Turkish, the language that is always mentioned as a paradigm case of an agglutinative language (cf. 22b)? It is well-known that Turkish has suffixes which vary by vowel harmony (and a kind of consonant harmony), e.g. Ístanbul'da 'in Istanbul' vs. Paris'te 'in Paris'. So is the locative suffix -da/-de/-ta/-te welded, according to our definition? I would say that it is, because vowel harmony is a morphophonological alternation, not an automatic phonetic alternation (recall the three-way distinction in (14)). But as I said, the precise boundaries are not agreed among linguists, ${ }^{23}$ and it would take a major effort to come up with clear types and technical terms for them that can be applied in an objective way.

But Plungian and Payne also add cumulation as an additional ingredient of flective languages, in line with the earlier literature. ${ }^{24}$ For example, like Latin and Sanskrit in (22c-d), Russian shows cumulation of case and number meanings (24a), while Modern Armenian does not $(24 b)$.

$\begin{array}{llllll} & \text { NOM.SG } & \text { INS.SG } & \text { NOM.PL } & \text { INS.PL } & \\ \text { a. Russian } & \text { sten- } a & \text { sten-oj } & \text { sten-y } & \text { sten-ami } & \text { 'wall(s)' } \\ \text { b. Armenian } & \text { ban- } \varnothing & \text { ban-ov } & \text { ban-er- } \varnothing & \text { ban-er-ov } & \text { 'thing(s)' }\end{array}$

But is cumulation closely related to weldedness of forms? As I noted earlier, cumulation is not common, while welded forms are extremely common in the world's languages. And in an earlier preliminary study (Haspelmath 2009), I did not find that weldedness correlates with cumulation.

The technical terms defined in the present paper do not allow us to make progress with regard to cumulation, because cumulation can be identified only if it is fully clear which grammatical meanings are expressed by a form. And this is rarely as clear as in the classical number and case paradigms. For Spanish verb inflection, Payne [2017: 88] notes that the form habl-ó 's/ he spoke' could be said to express five meanings (or "categories"): indicative mood, third person, singular number, past tense, and perfective aspect. But whether "perfective" and "past" are separate meanings is not quite clear (the aspectual contrast is not relevant for present and future tenses), and the "indicative meaning" is also not fully clear (there is no future subjunctive, and "subjunctive" forms are as much syntactically as semantically determined). So before we can compute a general "cumulation" index, we would have to find a way to determine the number of grammatical meanings that a form expresses.

Thus, the new, rigorously defined terms of the present paper help us only in limited ways in understanding whether the old "morphological typology" still has any value. It may well be that it will have to go the way of Blumenbach's classification of human races, and it may be wise for the moment to continue to put question marks behind all these terms (as was done in (22)).

${ }^{23}$ Alpatov [1985: 94] regards Turkish vowel harmony as purely phonological, not morphophonological (i.e. (14a), not (14b)). The reason why I do not regard it as an automatic phonetic alternation is that it is violated in many Turkish roots (of Arabic or Persian origin). Its effects can be seen by linguists also in non-borrowed roots, but it is obligatory in the language system only in morphological/morphosyntactic contexts.

${ }^{24}$ In addition, Plungian mentions suppletive alternations as in (14c) (cf. also [Haspelmath 2009]). These are sometimes mentioned as typical of flective languages, but they do not seem to have anything to do with "fusion" or "lack of clear morpheme boundaries" (so maybe they are mentioned primarily because they are common in Indo-European). 


\section{Back to the purposes of general terminology in linguistics}

It should have become clear by now that the simple definitions of common terms (bound form, affix, root) proposed in this paper are not based on brilliant new insights on how the perennial problems of grammatical terminology can be solved. However, what is probably quite new here (compared to attempts such as [Bloomfield 1933; Hockett 1947; Mel'čuk 1982; Mel'čuk 19932000]) are two realizations:

(25) General linguistics must be based on comparative concepts,

while particular linguistics must be based on language-particular categories.

(26) Widely used terms must be defined clearly as comparative concepts.

The first entails that the definitions must be independent of language-particular phenomena (principle D in (4)), which rules out many of the criteria that have been discussed in the literature. Of course, if one decided to follow the approach of "building block uniformity" (as is characteristic for traditional generative grammar), then the picture would look rather different: One may hypothesize that a category such as "affix" or "clitic" is an element of our innate grammar blueprint, and then there is no limit to the kinds of symptoms that one might use to identify affixes or clitics (cf. [Haspelmath 2015]). But if one has no great trust in a rich set of innate grammatical elements, then one must base general linguistics on comparative concepts.

The second realization is that if there is no clear definition of widely used terms, linguists will continue to be as confused as they have been over the last decades. Textbooks will continue to present salient examples and hope that their readers will somehow form the right concepts, based on the examples. But if a textbook does not define a term, the readers will not understand what it means and will instead create their own stereotype. This may often lead to the appearance of widespread agreement, as noted by Plungian [2011: 18]:

"As in many other cases, when we deal with traditional concepts of linguistics that rely on the intuition of speakers of European languages and a long descriptive practice, it is often much simpler to give an acceptable result of classification than to identify those criteria on which this result was based."

However, if the criteria are not clear, then the "acceptability" of a classification may be based on shared stereotypes rather than on true differences in the world (recall from $\S 3$ the failure of racial classifications, which were widely accepted for a long time, but which were shown to be without any scientific foundation).

Now it may of course turn out that the comparative definitions proposed here will not be particularly helpful, or rather that other definitions will be much more useful for gaining insights about Human Language. This is a separate question that I do not deal with here. But until we have clearly better general concepts and terms, we must continue working with terms like "affix" and "root", and they should have clear and simple definitions. ${ }^{25}$ (Other terms, such as "finite" or "markedness", may not be amenable to retrodefinition, so they should be abandoned. But in general, proposing a retrodefinition is preferable to proposing abandoning a term, because such negative recommendations are rarely effective.)

${ }^{25} \mathrm{~A}$ reviewer asked whether it is a scientific requirement that frequently used terms should have simple definitions (recall principle B in (4)). The answer is of course no: It is a purely practical requirement, and if we had very good reasons to think that an affix concept that requires a very complex definition is needed, then we should use such a definition for this term. But since we do not know much about what concepts yield the best results, we should choose a simple definition (for practical, including pedagogical purposes). 
Finally, there is a further question that some readers may have: Need the definitions be categorical, as I have presented them in this paper? Wouldn't it be more appropriate to have definitions that are fuzzy or vague, corresponding to the fuzziness or continuity that we find in the actual world (cf. [Plungian 2000: 20])? The reason why I think that the definitions cannot be fuzzy or prototype-based is that we need these terms in order to test hypotheses. The terms are our "units of measurement", analogous to the SI units in physics. It does indeed seem to be the case that many languages have more or less fuzzy categories. But some categories are not fuzzy at all. ${ }^{26}$ And while there are many cases of vagueness or unclarity of cross-linguistic concepts (what exactly is "finiteness" of verbs? what exactly is "left dislocation"?), there are other cases where cross-linguistic classification is very clear (e.g. demonstratives, question pronouns, numerals and negative markers are readily identified across languages).

So the extent to which a phenomenon is fuzzy is an empirical question, and to answer such questions, we need good research tools: general terms that are not defined in a stereotypical or subjective way, but in a simple straightforward way so that all linguists understand the terms in the same way. It appears that many linguists think that this is not possible or not a worthwhile task, but this paper has tried to show that it is possible (at least for bound and welded forms and for affixes), as long as one understands that the definitions must sometimes be shared-core definitions (principle E, §7). But since the definitions are comparative definitions anyway and cannot be applied to particular languages, this is not a defect of these definitions.

\section{ABBREVIATIONS}

$\begin{array}{llll}\text { ACC - accusative } & \text { GEN - genitive } & \text { NOM - nominative } & \text { PRS - present } \\ \text { DAT - dative } & \text { IMPV - imperative } & \text { OBL - oblique } & \text { SG - singular } \\ \text { DIM - diminutive } & \text { INF - infinitive } & \text { PL - plural } & \text { QP - question particle } \\ \text { F - feminine } & \text { INS - instrumental } & \text { PROG - progressive } & \end{array}$

\section{REFERENCES}

Alpatov 1985 - Алпатов В. М. Об уточнении понятий «флективный язык» и «агглютинативный язык». Лингвистическая типология. Солнцев В. М., Вардуль И. Ф. (ред.). М.: Наука, 1985, 92-101. [Alpatov V. M. On elaboration of the notions 'flective language' and 'agglutinative language'. Lingvisticheskaya tipologiya. Solntsev V. M., Vardul’ I. F. (eds.). Moscow: Nauka, 1985, 92-101.]

Alpatov 2018 - Алпатов В. М. Слово и части речи. М.: Издательский дом «ЯСК», 2018. [Alpatov V. M. Slovo i chasti rechi [Word and parts of speech]. Moscow: YaSK Publishing House, 2018.]

Anderson 1992 - Anderson S. R. A-morphous morphology. Cambridge: Cambridge Univ. Press, 1992.

Anderson 2008 - Anderson S. R. The logical structure of linguistic theory. Language, 2008, 84(4): 795814. https://doi.org/10.1353/lan.0.0075.

Arkadiev 2020 - Arkadiev P. M. Morphology in typology: Historical retrospect, state of the art, and prospects. Oxford research encyclopedia of linguistics. Aronoff M. et al. (eds.). Oxford: Oxford Univ. Press, 2020. https://doi.org/10.1093/acrefore/9780199384655.013.626.

Aronoff, Fudeman 2011 - Aronoff M., Fudeman K. A. What is morphology? $2^{\text {nd }}$ edn. Chichester: Wiley-Blackwell, 2011.

Bauer 2019 - Bauer L. Rethinking morphology. Edinburgh: Edinburgh Univ. Press, 2019.

Bickel, Nichols 2013 - Bickel B., Nichols J. Sampling case and tense formatives. The world atlas of language structures online. Dryer M. S., Haspelmath M. (eds.). Leipzig: Max Planck Institute for Evolutionary Anthropology, 2013. https://wals.info/chapter/s5.

Bickel, Zúñiga 2017 - Bickel B., Zúñiga F. The "word" in polysynthetic languages: Phonological and syntactic challenges. The Oxford handbook of polysynthesis. Fortescue M., Mithun M., Evans N. (eds.). Oxford: Oxford Univ. Press, 2017. https://doi.org/10.1093/oxfordhb/9780199683208.013.52.

${ }^{26}$ For example, it is very clear what a verb is in Russian, or what a vowel is in German; there do not seem to be any unclear cases of "verb-noun" hybrids or "vowel-consonant hybrids" in these languages. 
Bloomfield 1933 - Bloomfield L. Language. New York: H. Holt and Company, 1933.

Börjars 2003 - Börjars K. Morphological status and (de)grammaticalisation: The Swedish possessive. Nordic Journal of Linguistics, 2003, 26(2): 133-163. https://doi.org/10.1017/S0332586503001069.

Boye, Harder 2012 - Boye K., Harder P. A usage-based theory of grammatical status and grammaticalization. Language, 2012, 88(1): 1-44.

Brown 2005 - Brown C. H. Hand and arm. The world atlas of language structures. Haspelmath M., Dryer M. S, Gil D., Comrie B. (eds.). Oxford: Oxford Univ. Press, 2005, 522-525. http://wals.info/ chapter/s6.

Bybee 1985 - Bybee J. L. Morphology: A study of the relation between meaning and form. Amsterdam: John Benjamins, 1985.

Comrie 1978 - Comrie B. Ergativity. Syntactic typology: Studies in the phenomenology of language. Lehmann W. P. (ed.). Austin: Univ. of Texas Press, 1978, 329-394.

Comrie 1989 - Comrie B. Language universals and linguistic typology: Syntax and morphology. Oxford: Blackwell, 1989.

Croft 1991 - Croft W. Syntactic categories and grammatical relations: The cognitive organization of information. Chicago: Univ. of Chicago Press, 1991.

Crysmann 2006 - Crysmann B. Floating affixes in Polish. Proc. of the $13^{\text {th }}$ International Conf. on Head-Driven Phrase Structure Grammar. Müller S. (ed.). Stanford (CA): CSLI, 2006, 123-139.

Dixon 2010 - Dixon R. M. W. Basic linguistic theory. Vol. 1. Oxford: Oxford Univ. Press, 2010.

Dixon 1979 - Dixon R. M. W. Ergativity. Language, 1979, 55: 59-138.

Dressler 1985 - Dressler W. U. Morphonology. Ann Arbor (MI): Karoma Publ., 1985.

Foley, Van Valin 1977 - Foley W. A., Van Valin R. D. On the viability of the notion of "subject" in universal grammar. Berkeley Linguistics Society, 1977, 3: 293-320.

Gil 2008 - Gil D. How complex are isolating languages? Language complexity: Typology, contact, change. Miestamo M., Sinnemäki K., Karlsson F. (eds.). Amsterdam: John Benjamins, 2008, 109-131.

Greenberg 1960 - Greenberg J. H. A quantitative approach to the morphological typology of language. International Journal of American Linguistics, 1960, 26(3): 178-194.

Greenberg 1974 - Greenberg J. H. Language typology: A historical and analytic overview. The Hague: Mouton, 1974.

Halpern 1995 - Halpern A. On the placement and morphology of clitics. Stanford (CA): CSLI Publications, 1995.

Haspelmath 2002 - Haspelmath M. Understanding morphology. London: Arnold, 2002.

Haspelmath 2009 - Haspelmath M. An empirical test of the Agglutination Hypothesis. Universals of language today. Scalise S., Magni E., Bisetto A. (eds.). Dordrecht: Springer, 2009, 13-29. (Accessed May 27, 2016.)

Haspelmath 2011a - Haspelmath M. On S, A, P, T, and R as comparative concepts for alignment typology. Linguistic Typology, 2011, 15(3): 535-567.

Haspelmath $2011 \mathrm{~b}$ - Haspelmath M. The indeterminacy of word segmentation and the nature of morphology and syntax. Folia Linguistica, 2011, 45(1): 31-80.

Haspelmath 2012 - Haspelmath M. How to compare major word-classes across the world's languages. Theories of everything: In honor of Edward Keenan. (UCLA Working Papers in Linguistics, 17.) Graf T., Paperno D., Szabolcsi A., Tellings J. (eds.). Los Angeles: UCLA, 2012, 109-130.

Haspelmath 2013 - Haspelmath M. Argument indexing: A conceptual framework for the syntax of bound person forms. Languages across boundaries: Studies in memory of Anna Siewierska. Bakker D., Haspelmath M. (eds.). Berlin: De Gruyter Mouton, 2013, 197-226.

Haspelmath 2015 - Haspelmath M. Defining vs. diagnosing linguistic categories: A case study of clitic phenomena. How categorical are categories? New approaches to the old questions of noun, verb, and adjective. Błaszczak J., Klimek-Jankowska D., Migdalski K. (eds.). Berlin: De Gruyter Mouton. 2015, 273-304.

Haspelmath 2019 - Haspelmath M. Indexing and flagging, and head and dependent marking. Te Reo, 2019, 62(1): 93-115. https://doi.org/10.17617/2.3168042.

Haspelmath 2020 - Haspelmath M. The morph as a minimal linguistic form. Morphology, 2020, 30(2): 117-134. https://doi.org/10.1007/s11525-020-09355-5.

Haspelmath 2021 - Haspelmath M. Word class universals and language-particular analysis. 2021. To appear in Oxford handbook of word classes, ed. by Eva van Lier.

Haspelmath, Michaelis 2017 - Haspelmath M., Michaelis S. M. Analytic and synthetic: Typological change in varieties of European languages. Language variation - European perspectives VI: Selected 
papers from the $8^{\text {th }}$ International Conf. on Language Variation in Europe (ICLaVE 8), Leipzig 2015. Buchstaller I., Siebenhaar B. (eds.). Amsterdam: John Benjamins, 2017.

Hockett 1947 - Hockett C. F. Problems of morphemic analysis. Language, 1947, 23(4): 321-343. https:// doi.org/10.2307/410295.

Hockett 1958 - Hockett C. F. A course in modern linguistics. New York: MacMillan, 1958.

Horne 1970 - Horne K. M. Language typology: $19^{\text {th }}$ and $20^{\text {th }}$ century views. Washington: Georgetown Univ. Press, 1970.

Humboldt 1822 - von Humboldt W. Über das Entstehen der grammatischen Formen und ihren Einfluss auf die Ideenentwicklung. Abhandlungen der Akademie der Wissenschaften zu Berlin, 1822: 31-63.

Jackendoff, Audring 2020 — Jackendoff R., Audring J. The texture of the lexicon: Relational Morphology and the Parallel Architecture. Oxford: Oxford Univ. Press, 2020.

Kibrik 1997 - Kibrik A. E. Beyond subject and object: Toward a comprehensive relational typology. Linguistic Typology, 1997, 1(3): 279-346.

Kiparsky 1996 - Kiparsky P. Allomorphy or morphophonology? Trubetzkoy's orphan. Singh R., Desrochers R. (eds.). Amsterdam: John Benjamins, 1996, 13-31.

Lehmann 1982/2015 — Lehmann C. Thoughts on grammaticalization. Berlin: Language Science Press, 2015. (Originally published in 1982.) http://langsci-press.org/catalog/book/88.

List et al. 2018 - List J.-M., Greenhill S. J., Anderson C., Mayer T., Tresoldi T., Forkel R. CLICS2: An improved database of cross-linguistic colexifications assembling lexical data with the help of cross-linguistic data formats. Linguistic Typology, 2018, 22(2): 277-306. https://doi.org/10.1515/ lingty-2018-0010.

Lyons 1968 - Lyons J. Introduction to theoretical linguistics. Cambridge: Cambridge Univ. Press, 1968.

Mel'čuk 1982 - Mel'čuk I. A. Towards a language of linguistics: A system of formal notions for theoretical morphology. München: Fink, 1982.

Mel'čuk 1993-2000 - Mel'čuk I. Cours de morphologie générale (théorique et descriptive). Vol. I-V. Montréal: Presses de l'Université de Montréal; CNRS Éditions, 1993-2000.

Miller 1992 - Miller P. H. Clitics and constituents in phrase structure grammar. New York: Garland, 1992.

Monachesi 1999 - Monachesi P. A lexical approach to Italian cliticization. Stanford (CA): CSLI Publications, 1999.

Payne 2017 - Payne T. E. Morphological typology. The Cambridge handbook of linguistic typology. Aikhenvald A. Y., Dixon R. M. W. (eds.). Cambridge: Cambridge Univ. Press. 2017, 78-94. https://doi. org/10.1017/9781316135716.017.

Pinker 1999 - Pinker S. Words and rules: The ingredients of language. New York: Harper Collins, 1999.

Plank 1994 - Plank F. Inflection and derivation. Encyclopedia of language and linguistics. Asher R. E. (ed.). Oxford: Pergamon, 1994, 1671-1678.

Plungian 2000 - Плунгян В. А. Общая морфология: Введение в проблематику. М.: УРСС, 2000. [Plungian V. A. Obshchaya morfologiya: Vvedenie v problematiku [General morphology: Introduction to the problematics]. Moscow: URSS, 2000.]

Plungian 2001 - Plungian V. A. Agglutination and flection. Language typology and language universals: An international handbook. Vol. 1. Haspelmath M., König E., Oesterreicher W., Raible W. (eds.). Berlin: Walter de Gruyter, 2001, 669-678.

Plungian 2011 - Плунгян В. А. Введение в грамматическую семантику: Грамматические значения и грамматические системы языков мира. М.: РГГУ, 2011. [Plungian V. A. Vvedenie v grammaticheskuyu semantiku: Grammaticheskie znacheniya i grammaticheskie sistemy yazykov mira [Introduction to grammatical semantics: Grammatical meanings and grammatical systems of the world's languages]. Moscow: Russian State Univ. for the Humanities, 2011.]

Plungian, Semionova 2016 - Плунгян В. А., Семенова Кс. П. К типологии древнеармянской именной парадигматики: Instr.PL. Bопросы языкознания, 2016, 5: 103-118. [Plungian V. A., Semionova X. P. Towards a typology of Classical Armenian nominal paradigms: Instr.PL. Voprosy Jazykoznanija, 2016, 5: 103-118.]

Sapir 1921 - Sapir E. Language: An introduction to the study of speech. New York: Harcourt, Brace, Co., 1921.

A. W. Schlegel 1818 - von Schlegel A. W. Observations sur la langue et la littérature provençales. Paris: Librairie grecque-latine-allemande, 1818.

F. Schlegel 1808 - von Schlegel F. Ueber die Sprache und Weisheit der Indier: Ein Beitrag zur Begründung der Alterthumskunde. Heidelberg: Mohr und Zimmer, 1808.

Spencer 2013 - Spencer A. Lexical relatedness. Oxford: Oxford Univ. Press, 2013. 
Spencer, Otoguro 2005 - Spencer A., Otoguro R. Limits to case: A critical survey of the notion. Competition and variation in natural languages: The case for case. Amberber M., de Hoop H. (eds.). Oxford: Elsevier, 2005, 119-145.

Tallman 2020 - Tallman A. J. R. Beyond grammatical and phonological words. Language and Linguistics Compass, 2020, 14(2): e12364. https://doi.org/10.1111/lnc3.12364.

Zaliznyak 1967 - Зализняк А. А. Русское именное словоизменение. М.: Наука, 1967. [Zaliznyak A. A. Russkoe imennoe slovoizmenenie [Russian nominal inflection]. Moscow: Nauka. 1967.]

Zwicky 1977 - Zwicky A. M. On clitics. Bloomington: Indiana Univ. Linguistics Club, 1977.

Zwicky, Pullum 1983 - Zwicky A. M., Pullum G. K. Cliticization vs. inflection: English n't. Language, 1983, 59(3): 502-513.

Получено / received 16.07.2020

Принято / accepted 23.09.2020 